\title{
Identification of a Novel Missense KRT12 Mutation in a Vietnamese Family with Meesmann Corneal Dystrophy
}

\author{
Pham Ngoc Dong ${ }^{a}$ Le Xuan Cung ${ }^{a}$ Tran Khanh Sam ${ }^{a}$ \\ Do Thi Thuy Hang ${ }^{a}$ Doug D. Chung ${ }^{\text {b }}$ Turad A. Alkadi ${ }^{b, c}$ \\ Arjun Buckshey $^{\mathrm{b}}$ Junwei Zhang ${ }^{\mathrm{b}}$ Alexa Kassels ${ }^{\mathrm{b}}$ Anthony J. Aldave ${ }^{\mathrm{b}}$ \\ aVietnam National Eye Hospital, Hanoi, Vietnam; bStein Eye Institute, David Geffen School \\ of Medicine at UCLA, Los Angeles, CA, USA; 'CAI-Imam Muhammad Ibn Saud Islamic \\ University, Riyadh, Saudi Arabia
}

\section{Keywords}

Corneal dystrophy $\cdot$ Meesmann corneal dystrophy $\cdot$ Corneal epithelial disease $\cdot$ KRT12

\begin{abstract}
Meesmann epithelial corneal dystrophy (MECD) is a rare dominantly inherited disorder that is characterized by corneal epithelial microcysts and is associated with mutations in the keratin 3 (KRT3) and keratin 12 (KRT12) genes. In this study, we report a novel mutation in the KRT12 gene in a Vietnamese pedigree with MECD. Slit-lamp examination was performed on each of the 7 recruited members of a Vietnamese family to identify characteristic features of MECD. After informed consent was obtained from each individual, genomic DNA was isolated from saliva samples and screening of KRT3 and KRT12 genes was performed by Sanger sequencing. The proband, a 31-year-old man, complained of a 1year history of eye irritation and photophobia. Slit-lamp examination revealed intraepithelial microcysts involving only the corneal periphery in each eye with clear central corneas and no stromal or endothelial involvement. Three family members demonstrated similar intraepithelial microcysts, but with diffuse involvement, extended from limbus to limbus. Sanger sequencing of KRT3 (exon 7) and KRT12 (exons 1 and 6) in the proband
\end{abstract}




\section{Case Reports in Ophthalmology}

revealed a novel heterozygous KRT12 variant (c.1273G >A [p.Glu425Lys]) that was present in the three affected family members but was absent in the three family members with clear corneas. This study is the first report of a Vietnamese family affected with MECD, associated with an atypical peripheral corneal epithelial phenotype in the proband and a novel mutation in KRT12.

(C) 2020 The Author(s)

Published by S. Karger AG, Basel

\section{Introduction}

Meesmann epithelial corneal dystrophy (MECD; OMIM 122100) is a rare autosomal dominant inherited disorder of the corneal epithelium that is characterized by small round epithelial microcysts with onset as early as birth [1-3]. While MECD can be asymptomatic, affected individuals commonly experience ocular symptoms that include contact lens intolerance, foreign body sensation, lacrimation and photophobia. MECD is associated with mutations in the keratin 3 (KRT3) and keratin 12 (KRT12) genes, which encode cornea-specific keratins that form K3/K12 protein heterodimers responsible for imparting mechanical and structural integrity of the corneal epithelium. To date, 4 KRT3 mutations and 24 KRT12 mutations have been associated with MECD [3-23]. Each mutation is located in either the highly conserved helix initiation (located in exon 1 of KRT3 and KRT12) or helix termination (located in exon 7 of KRT3 and exon 6 of KRT12) motifs of the genes and is hypothesized to act in a dominant negative manner to cause MECD [3, 24]. KRT3 and KRT12 mutations have been identified in German, Chinese, Taiwanese, Japanese, Danish, Swiss, and American families affected with MECD but so far, there are no reports of mutations from Southeast Asia [4-7, 15, 17, 21, 22]. Here, we report a novel KRT12 missense mutation in a three-generation Vietnamese family affected with MECD.

\section{Case Presentation}

A 31-year-old Vietnamese man (Fig. 1a, II-2) presented to the Vietnam National Eye Hospital with a 1-year history of recurrent episodes of ocular irritation and frequent photophobia. Uncorrected visual acuity measured $20 / 20$ in each eye. Slit-lamp biomicroscopy revealed numerous small, clear, confluent intraepithelial cysts confined to the peripheral cornea of each eye, with a clear boundary between the involved and normal epithelium (Fig. 2a, b). The corneal stroma and endothelium were not involved, and the remaining of the eye examination was within normal limits. Slit-lamp biomicroscopy of the proband's 56-year-old mother (Fig. $1 \mathrm{a}, \mathrm{I}-2)$, who was diagnosed with cataract in both eyes and had counting fingers at $1 \mathrm{~m}$ visual acuity in each eye, revealed diffuse intraepithelial cysts extending from limbus to limbus in each eye (Fig. 2c). The proband's 35-year-old brother (Fig. 1a, II-1), who denied ocular complaints and had uncorrected visual acuity of 20/20 in both eyes, presented with diffuse intraepithelial cysts extending from limbus to limbus in each cornea (Fig. 2d), similar to his mother. The proband's 4-year-old daughter (Fig. 1a, III-1), for whom visual acuity testing could not be performed, also demonstrated bilateral diffusely distributed intraepithelial microcysts in both corneas.

\section{Genetic Screening}

Sanger sequencing of KRT3 (exon 7) and KRT12 (exons 1 and 6) in the proband (individual II:2) revealed a novel heterozygous c.1273G>A (p.Glu425Lys) variant in KRT12 exon 6 
(Fig. 2b). Screening of KRT12 exon 6 in 6 family members demonstrated segregation of the c. $1273 \mathrm{G}>\mathrm{A}$ variant with the affected phenotype, with its identification in the heterozygous state in three affected family members (Fig. 1a, individuals I:2, II:1, and III:1) and its absence in 3 unaffected family members (Fig. 1a, I:1, II:3, and III:2).

\section{Methods}

DNA Isolation

Saliva samples were collected with the Oragene Saliva Collection Kit (DNA Genotek, Inc., Ottawa, ON, Canada). Genomic DNA was isolated using the Oragene prepIT-L2P Kit (DNA Genotek, Inc.) according to the manufacturer's instructions.

PCR Amplification and Sanger Sequencing of KRT3 and KRT12

Exon 7 of KRT3 (Refseq Gene ID: 3850) and exons 1 and 6 of KRT12 (Refseq Gene ID: 3859), the exons in which presumed pathogenic mutations associated with MECD have been identified, were amplified using previously published primers and polymerase chain reaction (PCR) conditions [4]. Briefly, DNA amplification by PCR was performed with KAPA 2G Robust DNA polymerase (Kapa Biosystems, Wilmington, MA, USA) according to the manufacturer's recommendations using 25-40 ng of genomic DNA and $240 \mathrm{nM}$ of each primer per $25 \mu \mathrm{L}$ reaction. The PCR protocol consisted of an initial denaturing step at $95^{\circ} \mathrm{C}$ for $3 \mathrm{~min}$, followed by 36 cycles of denaturing at $95^{\circ} \mathrm{C}$ for $30 \mathrm{~s}$, annealing at $60^{\circ} \mathrm{C}$ for $30 \mathrm{~s}$, and elongation at $72^{\circ} \mathrm{C}$ for $30 \mathrm{~s}$. Sanger sequencing was performed by Laragen, Inc. (Culver City, CA, USA).

\section{Discussion}

MECD can range from being asymptomatic to presenting with recurrent erosions leading to ocular irritation, photophobia and diminished visual acuity [3]. Similar to the TGFBI dystrophies, a genotype-phenotype correlation has been described for MECD. However, while different mutations in TGFBI are associated with distinct morphologies and distribution of the dystrophic deposits, the different mutations in KRT3 and KRT12 are associated with indistinguishable appearance of the corneal epithelial microcysts, although the distribution may be either interpalpebral or diffuse and patients may be either symptomatic or asymptomatic, depending on the associated mutation. In addition, MECD has been associated with "clear zones," devoid of microcysts, located in various regions of the corneal epithelium, including the central cornea, as in the proband that we report. Intrafamilial phenotypic variability in regards to the presence or absence of clear epithelial areas has also been reported in other families affected with MECD [17]. In such cases of intrafamilial phenotypic variability in which the proband demonstrates an uncommon manifestation of MECD, as in this case, molecular genetic analysis provides a definitive means of confirming or refuting the suspected clinical diagnosis.

The identified novel p.Glu425Lys mutation resides in the helix termination motif of keratin 12, which is consistent with previous studies that report MECD-associated KRT12 mutations localized to either the helix initiation or helix termination motifs. Additionally, the phenotypic variability of MECD observed in this family is also consistent with previous reports, which suggest that factors other than the identified KRT3 or KRT12 mutation are responsible for the observed intra- and interfamilial phenotypic variation [10].

The Vietnamese family with MECD that we report is the first from South East Asia. Since the first case of MECD was reported in an 8-year-old Dutch boy 84 years ago [1], affected 


\section{Case Reports in Ophthalmology}

\begin{tabular}{l|l}
\hline DOI: $10.1159 / 000506435$ & $\begin{array}{l}\text { C } 2020 \text { The Author(s). Published by S. Karger AG, Basel } \\
\text { www.karger.com/cop }\end{array}$ \\
\hline
\end{tabular}

Dong et al.: Novel KRT12 mutation in a Vietnamese Pedigree with MECD

individuals of other European (German and Swiss), American, and East Asian (Japanese, Chinese and Taiwanese) nationalities have been reported $[2,4,7,8,14,17,18,22,25,26]$. The absence of reported MECD cases from South East Asia and other regions may be due to regional variations in the prevalence of MECD, reporting bias, or a combination of the two. Regional variation in the prevalence of other inherited corneal dystrophies is well recognized. For example, the prevalence of autosomal recessive dystrophies, such as congenital hereditary endothelial corneal dystrophy, is higher in regions where consanguineous marriages occur more commonly, such as in parts of the Middle East and India [27-30]. The prevalence of autosomal dominantly inherited corneal dystrophies also varies by region, with the prevalence of Fuchs endothelial corneal dystrophy, posterior polymorphous corneal dystrophy and granular corneal dystrophy type 2 reported to be higher in individuals from Northern Europe, Czech Republic and South Korea, respectively [25, 31-33]. However, it is likely that the geographic clustering of reports of MECD is due at least in part to the location of centers with more established research programs producing a higher number of publications. Therefore, it is important for developing countries such as Vietnam to report genotype-phenotype correlations, such as this, in order to be able to compare and contrast the molecular genetic basis of the corneal dystrophies across regions and nationalities and to gain insight into the variety of corneal dystrophies encountered worldwide.

\section{Statement of Ethics}

Informed written consent to participate in this study and permission to publish the results of the research were obtained from each family member (UCLA IRB \# 11-000020).

\section{Disclosure Statement}

The authors declare that there are no conflicts of interest.

\section{Funding Sources}

Support was provided by National Eye Institute Grants (grant numbers R01 EY022082 [A.J.A.], P30 EY000331 [core grant]); the Walton Li Chair in Cornea and Uveitis (A.J.A.); the Stotter Revocable Trust; and an unrestricted grant to Stein Eye Institute from Research to Prevent Blindness.

\section{Author Contributions}

Pham Ngoc Dong, MD - Patient examination, collection of clinical data, preparation of the manuscript. Le Xuan Cung, MD - Patient examination, collection of clinical data, preparation of the manuscript. Tran Khanh Sam, MD - Patient examination, collection of clinical data, preparation of the manuscript. Do Thi Thuy Hang, MD - Patient examination, collection of clinical data, preparation of the manuscript. Doug D. Chung, $\mathrm{PhD}$ - Drafted and edited the manuscript; interpreted genetic screening results; prepared the figures. Turad A. Alkadi, MD - Edited the manuscript. Arjun Buckshey, MD - Performed genetic screening. Junwei Zhang - Performed 


\section{Case Reports in Ophthalmology} \begin{tabular}{l|l}
\hline DOI: $10.1159 / 000506435$ & $\begin{array}{l}\text { C } 2020 \text { The Author(s). Published by S. Karger AG, Basel } \\
\text { www.karger.com/cop }\end{array}$
\end{tabular}

Dong et al.: Novel KRT12 mutation in a Vietnamese Pedigree with MECD

genetic screening. Alexa Kassels - Performed genetic screening. Anthony J. Aldave, MD - Edited the manuscript; interpreted the clinical findings and genetic screening results.

\section{References}

1 Pameijer JK. Uber eine fremdartige familiare oberflachliche Hornhaut-verdanderung. Klin Monatsbl Augenheilkd. 1935;95:516-7.

2 Meesmann A. U“ber eine bisher nicht beschriebene, dominant vererbte Dystrophia epithelialis corneae. Ber Zusammenkunft Dtsch Ophthalmol Ges. 1938;52:154-8.

3 Irvine AD, Corden LD, Swensson O, Swensson B, Moore JE, Frazer DG, et al. Mutations in cornea-specific keratin K3 or K12 genes cause Meesmann's corneal dystrophy. Nat Genet. 1997 Jun;16(2):184-7.

4 Chen JL, Lin BR, Gee KM, Gee JA, Chung DW, Frausto RF, et al. Identification of presumed pathogenic KRT3 and KRT12 gene mutations associated with Meesmann corneal dystrophy. Mol Vis. 2015 Dec;21:1378-86.

5 Chen YT, Tseng SH, Chao SC. Novel mutations in the helix termination motif of keratin 3 and keratin 12 in 2 Taiwanese families with Meesmann corneal dystrophy. Cornea. 2005 Nov;24(8):928-32.

6 Clausen I, Duncker GI, Grünauer-Kloevekorn C. Identification of a novel mutation in the cornea specific keratin 12 gene causing Meesmann's corneal dystrophy in a German family. Mol Vis. 2010 May;16:954-60.

7 Coleman CM, Hannush S, Covello SP, Smith FJ, Uitto J, McLean WH. A novel mutation in the helix termination motif of keratin K12 in a US family with Meesmann corneal dystrophy. Am J Ophthalmol. 1999 Dec;128(6):687-91.

8 Corden LD, Swensson O, Swensson B, Rochels R, Wannke B, Thiel HJ, et al. A novel keratin 12 mutation in a German kindred with Meesmann’s corneal dystrophy. Br J Ophthalmol. 2000 May;84(5):527-30.

9 Corden LD, Swensson O, Swensson B, Smith FJ, Rochels R, Uitto J, et al. Molecular genetics of Meesmann's corneal dystrophy: ancestral and novel mutations in keratin 12 (K12) and complete sequence of the human KRT12 gene. Exp Eye Res. 2000 Jan;70(1):41-9.

10 Ehlers N, Hjortdal J, Nielsen K, Thiel HJ, Ørntoft T. Phenotypic variability in Meesmann's dystrophy: clinical review of the literature and presentation of a family genetically identical to the original family. Acta Ophthalmol. 2008 Feb;86(1):40-4.

11 Hassan H, Thaung C, Ebenezer ND, Larkin G, Hardcastle AJ, Tuft SJ. Severe Meesmann's epithelial corneal dystrophy phenotype due to a missense mutation in the helix-initiation motif of keratin 12. Eye (Lond). 2013 Mar;27(3):367-73.

12 Irvine AD, Coleman CM, Moore JE, Swensson O, Morgan SJ, McCarthy JH, et al. A novel mutation in KRT12 associated with Meesmann's epithelial corneal dystrophy. Br J Ophthalmol. 2002 Jul;86(7):729-32.

13 Irvine AD, McLean WH. Human keratin diseases: the increasing spectrum of disease and subtlety of the phenotype-genotype correlation. Br J Dermatol. 1999 May;140(5):815-28.

14 Nichini O, Manzi V, Munier FL, Schorderet DF. Meesmann corneal dystrophy (MECD): report of 2 families and a novel mutation in the cornea specific keratin 12 (KRT12) gene. Ophthalmic Genet. 2005 Dec;26(4):169-73.

15 Nielsen K, Orntoft T, Hjortdal J, Rasmussen T, Ehlers N. A novel mutation as the basis for asymptomatic meesmann dystrophy in a Danish family. Cornea. 2008 Jan;27(1):100-2.

16 Nishida K, Honma Y, Dota A, Kawasaki S, Adachi W, Nakamura T, et al. Isolation and chromosomal localization of a cornea-specific human keratin 12 gene and detection of four mutations in Meesmann corneal epithelial dystrophy. Am J Hum Genet. 1997 Dec;61(6):1268-75.

17 Ogasawara M, Matsumoto Y, Hayashi T, Ohno K, Yamada H, Kawakita T, et al. KRT12 mutations and in vivo confocal microscopy in two Japanese families with Meesmann corneal dystrophy. Am J Ophthalmol. 2014 Jan;157(1):93-102.e1.

18 Seto T, Fujiki K, Kishishita H, Fujimaki T, Murakami A, Kanai A. A novel mutation in the cornea-specific keratin 12 gene in Meesmann corneal dystrophy. Jpn J Ophthalmol. 2008 May-Jun;52(3):224-6.

19 Sullivan LS, Baylin EB, Font R, Daiger SP, Pepose JS, Clinch TE, et al. A novel mutation of the Keratin 12 gene responsible for a severe phenotype of Meesmann's corneal dystrophy. Mol Vis. 2007 Jun;13:975-80.

20 Szaflik JP, Ołdak M, Maksym RB, Kamińska A, Pollak A, Udziela M, et al. Genetics of Meesmann corneal dystrophy: a novel mutation in the keratin 3 gene in an asymptomatic family suggests genotype-phenotype correlation. Mol Vis. 2008 Sep;14:1713-8.

21 Takahashi K, Takahashi K, Murakami A, Okisaka S, Kimura T, Kanai A. Heterozygous Ala137Pro mutation in keratin 12 gene found in Japanese with Meesmann's corneal dystrophy. Jpn J Ophthalmol. 2002 NovDec;46(6):673-4.

22 Wang LJ, Tian X, Zhang QS, Liu L. [Analysis of mutation in KRT12 gene in a Chinese family with Meesmann's corneal dystrophy]. Zhonghua Yan Ke Za Zhi. 2007 Oct;43(10):885-9. 
Dong et al.: Novel KRT12 mutation in a Vietnamese Pedigree with MECD

23 Yoon MK, Warren JF, Holsclaw DS, Gritz DC, Margolis TP. A novel arginine substitution mutation in 1A domain and a novel 27 bp insertion mutation in 2B domain of keratin 12 gene associated with Meesmann's corneal dystrophy. Br J Ophthalmol. 2004 Jun;88(6):752-6.

24 Omary MB, Coulombe PA, McLean WH. Intermediate filament proteins and their associated diseases. N Engl J Med. 2004 Nov;351(20):2087-100.

25 Cao W, Yan M, Hao Q, Wang S, Wu L, Liu Q, et al. Autosomal-dominant Meesmann epithelial corneal dystrophy without an exon mutation in the keratin-3 or keratin-12 gene in a Chinese family. J Int Med Res. 2013 Apr;41(2):511-8.

26 Meesmann AW. Klinische und anatomische Untersuchungen über eine bisher unbekannte, dominant vererbte Epitheldystrophie der Hornhaut. Klin Monatsbl Augenheilkd. 1939;103:361-391.

27 al Faran MF, Tabbara KF. Corneal dystrophies among patients undergoing keratoplasty in Saudi Arabia. Cornea. 1991 Jan;10(1):13-6.

28 Al-Towerki AE, Gonnah S, Al-Rajhi A, Wagoner MD. Changing indications for corneal transplantation at the King Khaled Eye Specialist Hospital (1983-2002). Cornea. 2004 Aug;23(6):584-8.

29 Dandona L, Ragu K, Janarthanan M, Naduvilath TJ, Shenoy R, Rao GN. Indications for penetrating keratoplasty in India. Indian J Ophthalmol. 1997 Sep;45(3):163-8.

30 Sony P, Sharma N, Sen S, Vajpayee RB. Indications of penetrating keratoplasty in northern India. Cornea. 2005 Nov;24(8):989-91.

31 Chae H, Kim M, Kim Y, Kim J, Kwon A, Choi H, et al. Mutational spectrum of Korean patients with corneal dystrophy. Clin Genet. 2016 Jun;89(6):678-89.

32 Eghrari AO, Gottsch JD. Fuchs' corneal dystrophy. Expert Rev Ophthalmol. 2010 Apr;5(2):147-59.

33 Liskova P, Gwilliam R, Filipec M, Jirsova K, Reinstein Merjava S, Deloukas P, et al. High prevalence of posterior polymorphous corneal dystrophy in the Czech Republic; linkage disequilibrium mapping and dating an ancestral mutation. PLoS One. 2012;7(9):e45495.

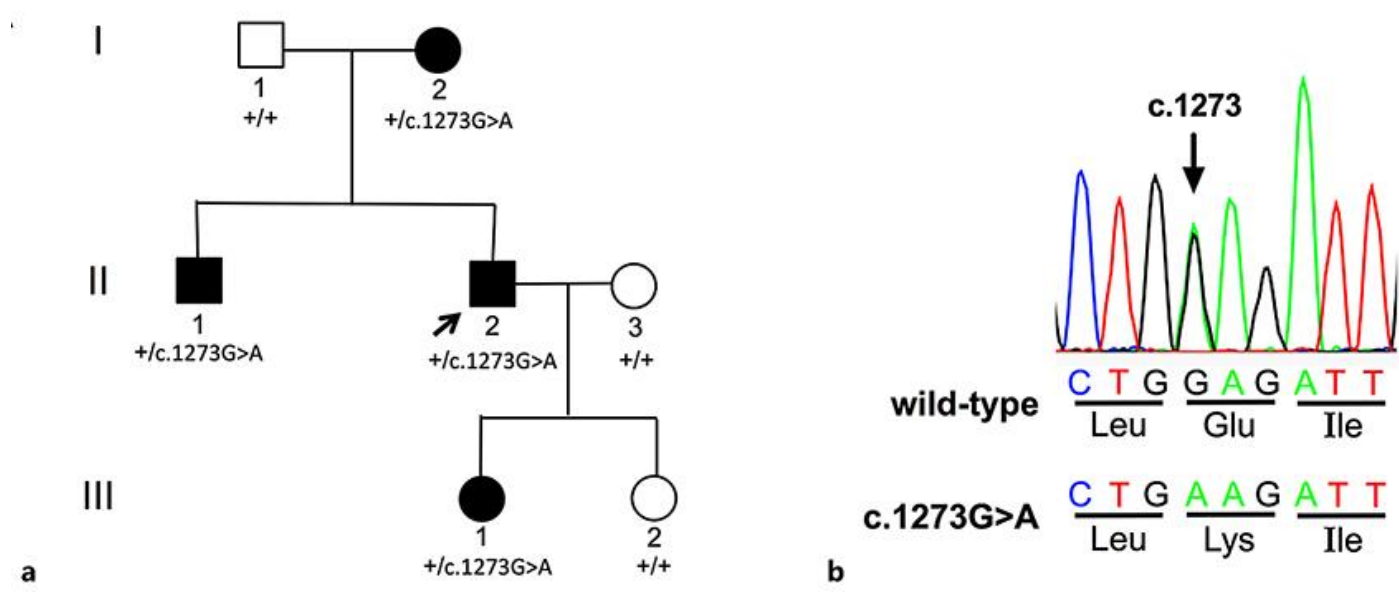

Fig. 1. a Pedigree of a Vietnamese family with Meesmann corneal dystrophy. Individuals heterozygous for the KRT12 c.1273G>A variant are indicated by +/c.1273G >A and individuals who lack the mutation are indicated by $+/+$. The proband is indicated by a black arrow. $\mathbf{b}$ Sanger sequencing demonstrates that the KRT12 c.1273G>A (p.Glu425Lys) variant is present in the proband and all affected family members. 


\section{Case Reports in Ophthalmology}
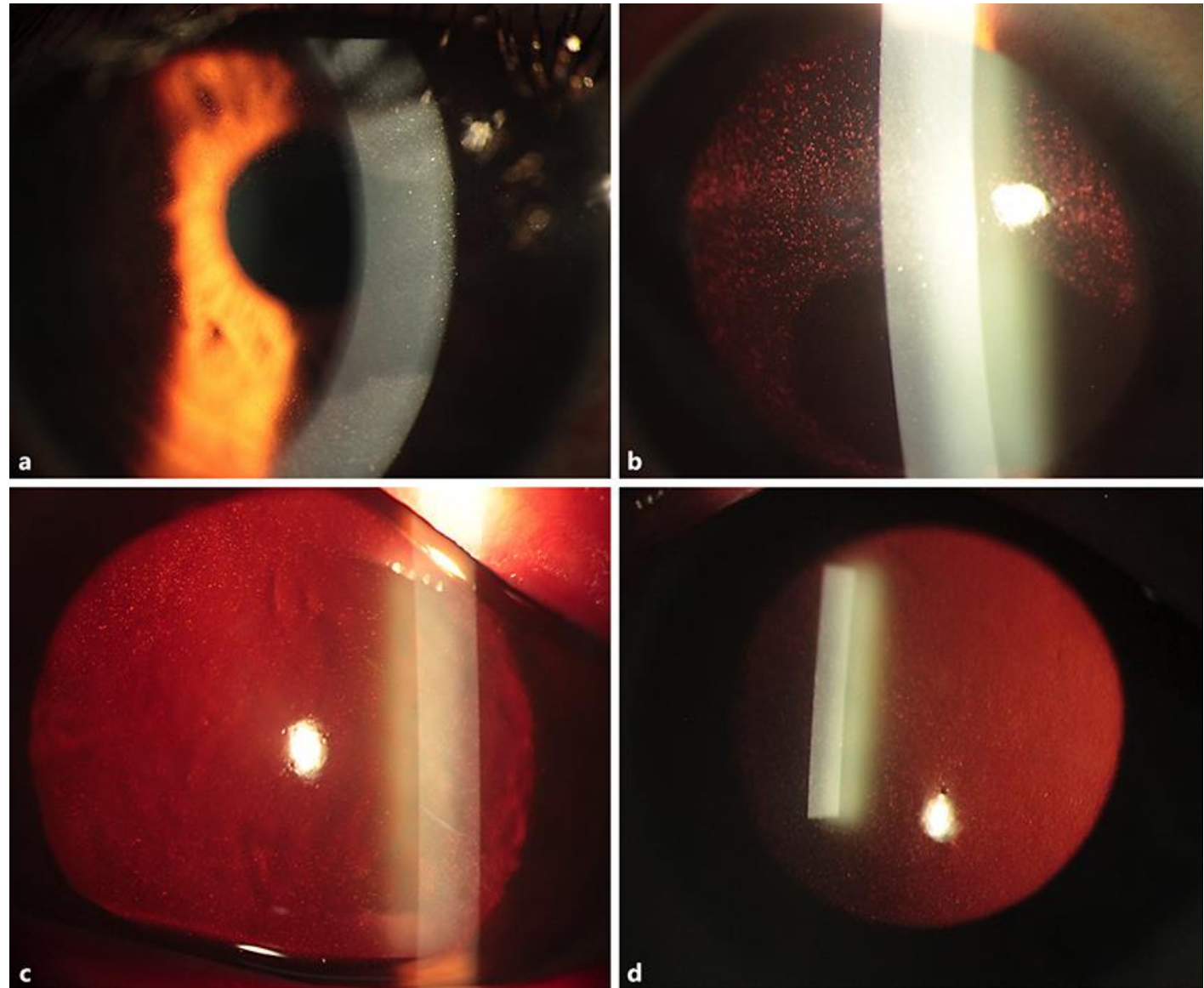

Fig. 2. Slit-lamp images of the 31-year-old proband's cornea, showing intraepithelial cysts in the periphery of the cornea sparing the central corneal epithelium, seen with both direct (a) and indirect (b) illumination. The proband's 56-year-old mother (c) and 35-year-old brother (d) demonstrated diffuse intraepithelial corneal microcysts on retro-illumination. 